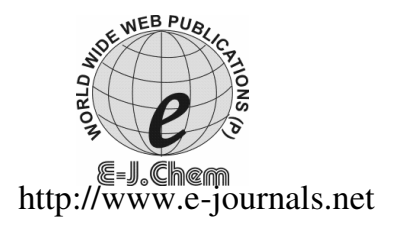

ISSN: 0973-4945; CODEN ECJHAO

E-Journal of Chemistry

2010, 7(4), 1190-1195

\title{
Syntheses, Characterization and Antimicrobial Evaluation of Some 1, 3, 5- Trisubustituted Pyrazole Derivatives
}

\author{
VERTIKA GAUTAM*, VINEY CHAWLA, \\ PANKAJ K. SONAR and SHAILENDRA K. SARAF \\ Faculty of Pharmacy, Northern India Engineering College, \\ Lucknow-227105, Uttar Pradesh, India. \\ dirpharmniec@gmail.com
}

Received 6 October 2009; Revised 17 December 2009; Accepted 10 February 2010

\begin{abstract}
A series of 1, 3, 5-trisubustituted pyrazole derivatives were synthesized and screened for antimicrobial activity. The compounds (2j-o) were evaluated against two gram-positive and two gram-negative bacteria and one fungus, at concentrations of $10 \mu \mathrm{g} / \mathrm{mL}$ and $50 \mu \mathrm{g} / \mathrm{mL}$. The compounds were founds to be inactive against $P$. aeruginosa and $A$. niger but exhibited moderate activity against $B$. subtilis, E. coli and $S$. aureus. It can be concluded that the newly synthesized compounds possess promising antimicrobial activity.
\end{abstract}

Keywords: Pyrazoles, Antimicrobial activity, Diketo compounds, FTIR.

\section{Introduction}

In the past few decades, the development of resistant microbes has been greatly accelerated by several concurrent trends. These have worked to increase the number of infections and thus expand the need for antimicrobials ${ }^{1}$.

In this situation, enlargement of innovative drugs with dual activity against bacterial and fungal pathogens is required to over come this problem ${ }^{2}$. Pyrazoles are important nitrogencontaining five-membered heterocyclic compounds possessing some important pharmacological activities like antitumour ${ }^{3}$, immunosuppressive $^{4}$, antibacterial ${ }^{5}$, antitubercular anti-inflammatory $^{6}$, anticancer ${ }^{7}$, antidiabetic ${ }^{8}$ and antidepressant properties ${ }^{9}$. Some novel pyrazolo[3,4-d] pyrimidine derivatives have been reported for antimicrobial potential against E. coli, S. aureus, P. aerunginosa, B. subtilis, C. albicans and A. fumigatus ${ }^{10}$. A series of 3, 4diarylpyrazoles was synthesized and evaluated for the ability to selectively inhibit cyclooxygenase-2 (COX-2) ${ }^{11}$. Pyrazole-4-carboxylic acid derivatives were found to possess in vivo hypoglycemic activity ${ }^{12}$. Some unsymmetrical $N$-endocyclic and $N$-exocyclic derivatives from benzoylation of 3- and 5- aminopyrazole were shown to have anticonvulsant activity ${ }^{13}$. 
Halogenated substituents can alter not only the course of the reaction but also the biological activities. Thus, introduction of chlorine atoms provide more lipophilic and pharmacologically significant compounds as compared to their non-halogenated analogues. The present research was intended to synthesize some novel1, 3, 5-trisubstituted chloroderivatives of pyrazole and evaluate them for antibacterial and antifungal activities.

\section{Experimental}

All the chemicals were of synthetic grade and procured from S. D. Fine-Chem. Limited; Mumbai and Sigma-Aldrich Chemie GmbH, Germany. Melting points were determined in open capillary tubes and are uncorrected. Thin Layer Chromatography was performed on precoated silica plates using chloroform: methanol (9:1). The spots were observed under ultraviolet lamp with short and long wavelength and also in an iodine chamber. The IR spectra of the compounds were recorded (in KBr) on a Shimadzu 8400 FTIR spectrophotometer and mass spectra on a Jeol/ SX-102/ DA-600 FAB mass spectrophotometer at SAIF, C.D.R.I., Lucknow.

The antimicrobial activity of the prepared compounds was determined by agar diffusion method in concentrations of 10 and $50 \mu \mathrm{g} / \mathrm{mL}$ in $10 \%$ DMSO against the microbial strains, MTCC 441 (Bacillus subtilis), MTCC 1430 (Staphylococcus aureus), MTCC 424 (Pseudomonas aeruginosa), MTCC 1573 (Escherichia coli) and MTCC 2546 (Aspergillus niger) respectively. Bacterial and fungal strains were procured from IMTECH, Chandigarh, India.

\section{Syntheses of diketo derivatives $\mathbf{1}(\boldsymbol{a}-\boldsymbol{c})$}

The sodium ethoxide was synthesized by routine method using dry sodium $(0.5 \mathrm{~mol})$ and refluxing it with absolute ethanol $(0.5 \mathrm{~mol}) .2 \mathrm{~mol}$ of pure dry ethyl acetate and $0.5 \mathrm{~mol}$ of substituted acetophenone were added in the synthesized sodium ethoxide $(0.5 \mathrm{~mol})$ to get corresponding sodium salt of diketo compounds (1a-c) after $2 \mathrm{~h}$ stirring on ice bath.

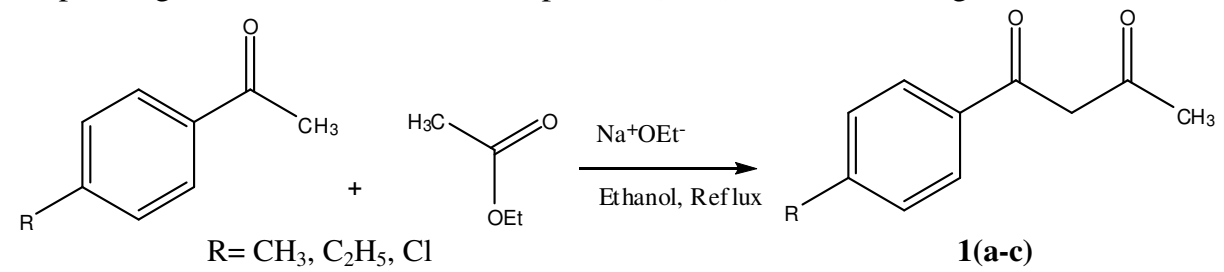

\section{Scheme 1}

\section{1-p-Tolylbutane-1, 3-dione (1a)}

Yield: $67.77 \%$, melting range $164-168{ }^{\circ} \mathrm{C}$. IR (KBr pellet) (Ar) C-H str, $2974 \mathrm{~cm}^{-1}$; C=O str, $1612 \mathrm{~cm}^{-1}$; (Aliphatic) C-H str, $1417 \mathrm{~cm}^{-1}$. FAB-MS m/z: $176\left(\mathrm{M}^{+}\right.$peak).

\section{1-(4-Ethylphenyl) butane-1, 3-dione (1b)}

Yield: $71.36 \%$, melting range $128-132{ }^{\circ} \mathrm{C}$. IR (KBr pellet) $\mathrm{C}=\mathrm{O}$ str, $1741.40 \mathrm{~cm}^{-1}$; (Aliphatic) C-H str, $1411 \mathrm{~cm}^{-1}$. FAB-MS m/z: 191 (M+1 peak).

\section{1-(4-Chlorophenyl) butane-1, 3-dione (1c)}

Yield: $77.77 \%$, melting range $112-116{ }^{\circ} \mathrm{C}$. IR (KBr pellet) (Ar) $\mathrm{C}-\mathrm{H} \mathrm{str}, 3415 \mathrm{~cm}^{-1}$; $\mathrm{C}=\mathrm{O}$ str, $1691.81 \mathrm{~cm}^{-1}$; (Ar) C-Cl str, $1098.83 \mathrm{~cm}^{-1}$. FAB-MS m/z: $196\left(\mathrm{M}^{+}\right.$peak).

Synthesis of p-nitro aryl derivatives of pyrazole (2a-c)

$0.01 \mathrm{Mol}$ of $p$-nitro phenyl hydrazine and a drop of aqueous $15 \%$ hydrochloric acid were slowly added to a solution of $0.01 \mathrm{~mol}$ of previously prepared diketo compounds (1a-c) in ethanol. 
<smiles>[R]c1ccc(C(=O)CC(C)=O)cc1</smiles>

(1a-c)

$\mathbf{R}_{1}=\mathrm{CH}_{3} \mathrm{Cl}, \mathrm{C}_{2} \mathrm{H}_{5} \mathrm{Cl}$.<smiles>[R]c1ccc(-c2cc(C)nn2-c2ccc([N+](=O)[O-])cc2)cc1</smiles>

$\mathrm{Sn} \downarrow \mathrm{HCl}$<smiles>C=CC=Cc1cc(C)n[nH]1</smiles><smiles>[R10]Nc1ccc(-n2nc(C)cc2-c2ccc([R])cc2)cc1</smiles>

Scheme 2<smiles>[R]c1ccc(-c2cc(C)nn2-c2ccc(N)cc2)cc1</smiles>

(2g-i)

After refluxing for $2 \mathrm{~h}$ and further evaporation of solvent, the residue was recrystallized from industrial spirit affording the pyrazoles (2a-c).

\section{3-Methyl-1-(4-nitrophenyl)-5-p-tolyl-1H-pyrazole (2a)}

Yield: $53.94 \%$, melting range $140-143{ }^{\circ} \mathrm{C}$. IR (KBr pellet) $\mathrm{N}-\mathrm{H}$ str, $3523.70 \mathrm{~cm}^{-1}$; Ring str, $1336.51 \mathrm{~cm}^{-1}$; (Ar) N=O str $1521.73 \mathrm{~cm}^{-1}$; (Ali) C-H str, $1456.16 \mathrm{~cm}^{-1}$. FAB-MS m/z: 293 $\left(\mathrm{M}^{+}\right.$peak).

\section{5-(4-Ethylphenyl)-3-methyl-1-(4-nitrophenyl)-1H-pyrazole (2b)}

Yield: $65.34 \%$, melting range $114-118{ }^{\circ} \mathrm{C}$. IR (KBr pellet) $\mathrm{N}-\mathrm{H}$ str, $3423.76 \mathrm{~cm}^{-1}$; Ring str, $1347.09 \mathrm{~cm}^{-1}$; (Ar) $\mathrm{N}=\mathrm{O}$ str $1521.73 \mathrm{~cm}^{-1}$; (Methyl) C-H str, $1697.24 \mathrm{~cm}^{-1}$. FAB-MS $m / z$ : $307\left(\mathrm{M}^{+}\right.$peak).

\section{5-(4-Chlorophenyl)-3-methyl-1-(4-nitrophenyl)-1H-pyrazole (2c)}

Yield: $75.87 \%$, melting range $102-105^{\circ} \mathrm{C}$. IR (KBr pellet) $\mathrm{N}-\mathrm{H}$ str, $3423.76 \mathrm{~cm}^{-1}$; Ring str, $1347.09 \mathrm{~cm}^{-1}$; (Ar) $\mathrm{N}=\mathrm{O}$ str $1521.73 \mathrm{~cm}^{-1}$; (Ar) C-Cl str, 1097.42. $\mathrm{cm}^{-1}$. FAB-MS m/z: 314 (M+1 peak). 


\section{Reduction of nitro group into amino group (2d-f)}

A solution of $0.01 \mathrm{~mol}$ of the synthesized $p$-nitroaryl derivatives of pyrazole (2a-c) and $0.15 \mathrm{~mol}$ of granulated tin in concentrated hydrochloric acid $(30 \mathrm{~mL})$ were placed in a roundbottomed flask, equipped with a reflux condenser and the shaken steadily to ensure thorough mixing. Finally, the mixture was heated on a boiling water bath for $1 \mathrm{~h}$, cooled to room temperature and a solution of $9 \mathrm{~g}$ of sodium hydroxide in $15 \mathrm{~mL}$ of water was gradually added. After cooling, the reduced product separated out and was extracted using ether.

\section{4-(3-Methyl-5-p-tolyl-1H-pyrazol-1-yl) aniline (2d)}

Yield: $56.67 \%$, melting range $96-98{ }^{\circ} \mathrm{C}$. IR (KBr pellet) (Htr) C-H str, $3076.25 \mathrm{~cm}^{-1}$; ( Htr) $\mathrm{N}-\mathrm{H}$ str, $3207.40 \mathrm{~cm}^{-1}$; Ring str, $1431.08 \mathrm{~cm}^{-1}$; C-N str $\left(-\mathrm{NH}_{2)}, 1317.29 \mathrm{~cm}^{-1}\right.$; (Methyl) C-H str, $2916.17 \mathrm{~cm}^{-1}$. FAB-MS m/z: 264 (M+1 peak).

\section{4-(5-(4-Ethylphenyl)-3-methyl-1H-pyrazol-1-yl) aniline (2e)}

Yield: $63.06 \%$, melting range $108-110^{\circ} \mathrm{C}$. IR (KBr pellet) (Htr) C-H str, $3076.25 \mathrm{~cm}^{-1}$; (Ar) $\mathrm{C}-\mathrm{H}$ str, $2916.17 \mathrm{~cm}^{-1}$; C-N str $\left(-\mathrm{NH}_{2}\right), 1232.43 \mathrm{~cm}^{-1}$; (Htr) N-H str, $3207.40 \mathrm{~cm}^{-1}$. FAB-MS $m / z: 277\left(\mathrm{M}^{+}\right.$peak).

\section{4-(5-(4-Chlorophenyl)-3-methyl-1H-pyrazol-1-yl) aniline (2f)}

Yield: $64.32 \%$, melting range $143-145^{\circ} \mathrm{C}$. IR (KBr pellet) (Htr) C-H str, $2923.89 \mathrm{~cm}^{-1}$; (Htr) $\mathrm{N}-\mathrm{H}$ str, $3442.70 \mathrm{~cm}^{-1}$; Ring str, $1396.36 \mathrm{~cm}^{-1}$; C-N str $\left(-\mathrm{NH}_{2}\right), 1306.72 \mathrm{~cm}^{-1}$; (Ar) C-Cl str, $1097.42 \mathrm{~cm}^{-1}$. FAB-MS m/z: 284 (M+1 peak).

\section{Synthesis of azide derivatives of pyrazole (2g-i)}

0.01 Mole of synthesized amine derivatives of pyrazole (2d-f) were added in a $20 \% \mathrm{v} / \mathrm{v}$ solution of sulfuric acid and the suspension was cooled to $0-5{ }^{\circ} \mathrm{C}$ in an ice-salt bath. A solution of sodium nitrite $(0.16 \mathrm{~mol})$ in $30 \mathrm{~mL}$ of water was added drop-wise over a period of 15 minutes. A thick precipitate of the sparingly soluble diazonium salt separated out from the initially clear solution. A solution of sodium azide $(0.17 \mathrm{~mol})$ in $40 \mathrm{~mL}$ of water was added with rapid stirring, which was continued for $1 \mathrm{~h}$. The solid was filtered, washed with water and dried.

\section{1-(4-Azidophenyl)-3-methyl-5-p-tolyl-1H-pyrazole (2g)}

Yield: $61.56 \%$, melting range $100-104{ }^{\circ} \mathrm{C}$. IR (KBr pellet) $(\mathrm{Htr}) \mathrm{C}-\mathrm{H}$ str, $2879.52 \mathrm{~cm}^{-1}$; (Htr) $\mathrm{N}-\mathrm{H}$ str, $3357.54 \mathrm{~cm}^{-1}$; C-N str $\left(-\mathrm{N}_{3}\right), 1306.72 \mathrm{~cm}^{-1}$. FAB-MS m/z: $289\left(\mathrm{M}^{+}\right.$peak).

\section{1-(4-Azidophenyl)-5-(4-ethylphenyl)-3-methyl-1H-pyrazole (2h)}

Yield: $57.98 \%$, melting range $180-185^{\circ} \mathrm{C}$. IR (KBr pellet) (Htr) N-H str, $3357.64 \mathrm{~cm}^{-1}$; Ring str, $1305.72 \mathrm{~cm}^{-1}$; C-N str $\left(-\mathrm{N}_{3}\right), 1305.08 \mathrm{~cm}^{-1}$. FAB-MS m/z: $303\left(\mathrm{M}^{+}\right.$peak).

\section{1-(4-Azidophenyl)-5-(4-chlorophenyl)-3-methyl-1H-pyrazole (2i)}

Yield: $53.23 \%$, melting range $110-115^{\circ} \mathrm{C}$. IR (KBr pellet) $(\mathrm{Htr}) \mathrm{C}-\mathrm{H} \mathrm{str}, 2923.89 \mathrm{~cm}^{-1}$; (Htr) N-H str, $3442.70 \mathrm{~cm}^{-1}$; C-N str $\left(-\mathrm{N}_{3}\right), 1306.72 \mathrm{~cm}^{-1}$; (Ar) C-Cl str, $1095.49 \mathrm{~cm}^{-1}$. FAB-MS $m / z: 309\left(\mathrm{M}^{+}\right.$peak).

\section{Syntheses of $N$-substituted aniline derivatives of pyrazole (2j-o)}

Equimolar quantities of the synthesized azide derivatives of pyrazole (2g-i) and methyl chloride were refluxed in ethanol for $3 \mathrm{~h}$. The reaction mixture was concentrated in a rotary evaporator, filtered and dried in a desiccator.

N-Methyl-4-(3-methyl-5-p-tolyl-1H-pyrazol-1-yl) aniline (2j)

Yield: $47.78 \%$, melting range $146-148^{\circ} \mathrm{C}$. IR (KBr pellet) (Htr) N-H str, $3475.40 \mathrm{~cm}^{-1}, 3417.63 \mathrm{~cm}^{-1}$; (Htr) C-H str, $3024.18 \mathrm{~cm}^{-1}$; C-N str (-NHR), $1348.13 \mathrm{~cm}^{-1}$. FAB-MS m/z: 277 (M peak). 
4-(5-(4-Ethylphenyl)-3-methyl-1H-pyrazol-1-yl)-N-methylaniline (2k)

Yield: $32.45 \%$, melting range $86-88^{\circ} \mathrm{C}$. IR (KBr pellet) (Htr) N-H str, $3321.10 \mathrm{~cm}^{-1}, 3415.70 \mathrm{~cm}^{-1}$; C-N str (-NHR), $1288.36 \mathrm{~cm}^{-1}$; Ring str, $1595.02 \mathrm{~cm}^{-1}$. FAB-MS m/z: $291\left(\mathrm{M}^{+}\right.$peak).

\section{4-(5-(4-Chlorophenyl)-3-methyl-1H-pyrazol-1-yl)-N-methylaniline (2l)}

Yield: $38.65 \%$, melting range $98-102{ }^{\circ} \mathrm{C}$. IR (KBr pellet) $(\mathrm{Htr}) \mathrm{N}-\mathrm{H}$ str, $3438.84 \mathrm{~cm}^{-1}$; C-N str (-NHR), $1255.57 \mathrm{~cm}^{-1}$; Ar C-Cl str, $1074.19 \mathrm{~cm}^{-1}$. FAB-MS m/z: 298 (M+1 peak).

N-Ethyl-4-(3-methyl-5-p-tolyl-1H-pyrazol-1-yl) aniline (2m)

Yield: $28.33 \%$, melting range $114-116^{\circ} \mathrm{C}$. IR (KBr pellet) (Htr) N-H str, $3489.40 \mathrm{~cm}^{-1}$; (Htr) C-H str, $3076.25 \mathrm{~cm}^{-1}$; C-N str (-NHR), $1317.29 \mathrm{~cm}^{-1}$. FAB-MS $m / z: 291$ (M+ peak).

N-Ethyl-4-(5-(4-ethylphenyl)-3-methyl-1H-pyrazol-1-yl) aniline (2n)

Yield: $34.89 \%$, melting range $163-165^{\circ} \mathrm{C}$. IR (KBr pellet) $(\mathrm{Htr}) \mathrm{N}-\mathrm{H} \mathrm{str}, 3305.76 \mathrm{~cm}^{-1}$; (Htr) C-H str, $3026.25 \mathrm{~cm}^{-1}$; C-N str (-NHR), $1317.29 \mathrm{~cm}^{-1}$. FAB-MS m/z: $305\left(\mathrm{M}^{+}\right.$peak).

4-(5-(4-Chlorophenyl)-3-methyl-1H-pyrazol-1-yl)-N-ethylaniline (2o)

Yield: $33.07 \%$, melting range $118-122{ }^{\circ} \mathrm{C}$. IR (KBr pellet) $(\mathrm{Htr}) \mathrm{N}-\mathrm{H} \mathrm{str}, 3442.70 \mathrm{~cm}^{-1}$; (Htr) C-H str, 2923.65 $\mathrm{cm}^{-1}$; C-N str (-NHR), $1305.72 \mathrm{~cm}^{-1}$; (Ar) C-Cl str, $1097.42 \mathrm{~cm}^{-1}$. FAB-MS $\mathrm{m} / \mathrm{z}: 311\left(\mathrm{M}^{+}\right.$peak).

\section{Anti-microbial activity}

The test organisms were inoculated in nutrient broth and were incubated for 48 hours. A definite volume of this suspension was mixed with nutrient agar (cooled to $40{ }^{\circ} \mathrm{C}$ ) and poured into petri plates to obtain a uniform thickness. Wells were prepared in the agar and filled with equal volume of respective solution of synthesized compounds (2j-o). After a period of pre-incubation diffusion, the plates were incubated in the specified conditions ${ }^{14,15}$. Zones of inhibition were measured with the help of zone reader and are reported in Table 1.

Table 1. Results of Antimicrobial activity of the tested compounds

\begin{tabular}{|c|c|c|c|c|c|c|}
\hline \multirow[t]{3}{*}{ Compounds } & \multirow{3}{*}{$\begin{array}{c}\text { Concentration, } \\
\mu \mathrm{g} / \mathrm{mL}\end{array}$} & \multicolumn{5}{|c|}{ Comparision of diameters of zones of inhibition, $\mathrm{mm}$} \\
\hline & & \multicolumn{2}{|c|}{ Gram +ve Bacteria } & \multicolumn{2}{|c|}{ Gram -ve Bacteria } & \multirow{2}{*}{$\frac{\text { Fungus }}{\text { A. niger }}$} \\
\hline & & B. subtils & S. aureus & P. aeruginosa & E. coli & \\
\hline \multirow{2}{*}{$2 \mathbf{j}$} & 50 & + & + & - & ++ & - \\
\hline & 10 & - & - & - & - & - \\
\hline \multirow{2}{*}{$2 \mathrm{k}$} & 50 & + & + & - & ++ & - \\
\hline & 10 & - & - & - & - & - \\
\hline \multirow{2}{*}{ 2l } & 50 & + & + & - & ++ & - \\
\hline & 10 & - & - & - & - & - \\
\hline \multirow{2}{*}{$2 \mathrm{~m}$} & 50 & + & + & - & ++ & - \\
\hline & 10 & - & - & - & - & - \\
\hline \multirow{2}{*}{$2 n$} & 50 & + & + & - & ++ & - \\
\hline & 10 & - & - & - & - & - \\
\hline \multirow{2}{*}{20} & 50 & + & + & + & ++ & + \\
\hline & 10 & - & - & - & - & - \\
\hline Norfloxacin & 10 & +++ & +++ & +++ & +++ & + \\
\hline Fluconazole & 10 & + & + & + & + & +++ \\
\hline Control (DMSO) & $10 \% \mathrm{v} / \mathrm{v}$ & - & - & - & - & - \\
\hline
\end{tabular}

Highly active $=+++($ zone of inhibition $>12 \mathrm{~mm})$, moderately active $=++($ zone of inhibition $>9-12 \mathrm{~mm})$, slightly active $=+($ zone of inhibition $>7-9 \mathrm{~mm})$, Inactive $=-($ zone of inhibition $<7 \mathrm{~mm})$. 


\section{Results and Discussion}

All compounds proposed in the scheme were synthesized using the pyrazole ring formed by the substrate diketo and $p$-nitro phenyl hydrazine and further derivatising by reduction and final substitution by alkyl halides.

The synthesized compounds were subjected to physicochemical and spectral characterization. Single spot in TLC established the purity of the compounds. IR and mass spectra confirmed the synthesis of intermediates and final compounds (2j-o). Antimicrobial activity of the final derivatives was determined by agar diffusion method and was found to be concentration dependent. None of the compounds was found to be effective against $P$. aeruginosa and $A$. niger. The compounds showed moderate activity at the concentration of $50 \mu \mathrm{g} / \mathrm{mL}$, against B. subtilis, S. aureus and E. coli

\section{Conclusion}

The study establishes that the 1,3,5-trisubstituted pyrazole derivatives exhibit antimicrobial activity. The activity of the derivatives is more pronounced for Gram-negative microorganisms than for the Gram-positive ones. However, the derivatives are almost inactive against the fungus.

The study thus provides a lead for the syntheses and evaluation of more pyrazole derivatives for antimicrobial activity as the same could lead to the discovery of some promising agents.

\section{References}

1. $\quad$ Chugh T D, J Biosci., 2008, 33, 549-555.

2. Williams D H, Nat Prod Rep., 1996, 13, 469.

3. Taylor E C and Patel H H, Tetrahedron, 1992, 48, 8089.

4. Lombardino J G and Otterness I G, J Med Chem., 1977, 20, 830.

5. Holla B S, Akberali P M and Shivananda M K, Farmaco, 2000, 55, 256-263.

6. Bansal E, Srivastava V K and Kumar A, Eur J Med Chem., 2001, 36, 81.

7. Manna F, Chementi F, Fioravanti R and Bolasco A, Bioorg Med Chem Lett., 2005, 15, 4632-4635.

8. Ahn J H, Kim H M, Jung S H, Kang S K, Kim K R, Rhee S D, Yong S D, Cheon H G and Kim S S, Bioorg Med Chem Lett., 2004, 14, 4461-4465.

9. Prasad Y R, Rao A L, Prasoona L, Murali K and Ravi K P, Bioorg Med Chem Lett., 2004, 14, 4461.

10. Holla B S, Mahalinga M, Karthikeyan M S, Akberali P M and Shetty N S, Bioorg Med Chem., 2006, 14, 2040-2047.

11. Penning TD, Kramer SW, Lee LF, Collins PW, Koboldt CM, Seibert K, Veenhuizen AW, Zhang YY and Isakson PC, Biorg Med Chem Lett.,1997, 7, 2121-2124.

12. Cottineau B, Toto P, Marot C, Pipaud A and Chenault J, Bioorg Med Chem Lett., 2002, 12, 2105.

13. Michon V, Herve du Penhoat C, Tombret F, Gillardin J M, Lepage F and Berthon L, Eur J Med Chem., 1995, 30, 147.

14. Biological assay, Indian Pharmacopoeia, 1996, 2, A-100.

15. Schmidt W H and Moyer A J, J Bacteriol., 1944, 17,199-209. 


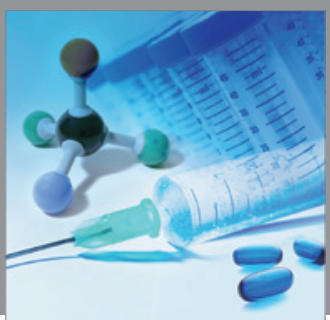

International Journal of

Medicinal Chemistry

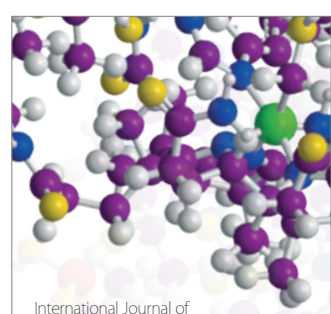

Carbohydrate Chemistry

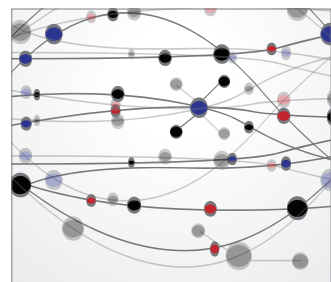

The Scientific World Journal
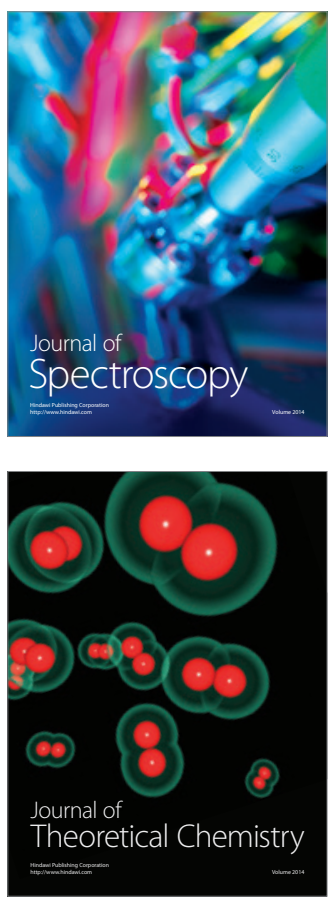
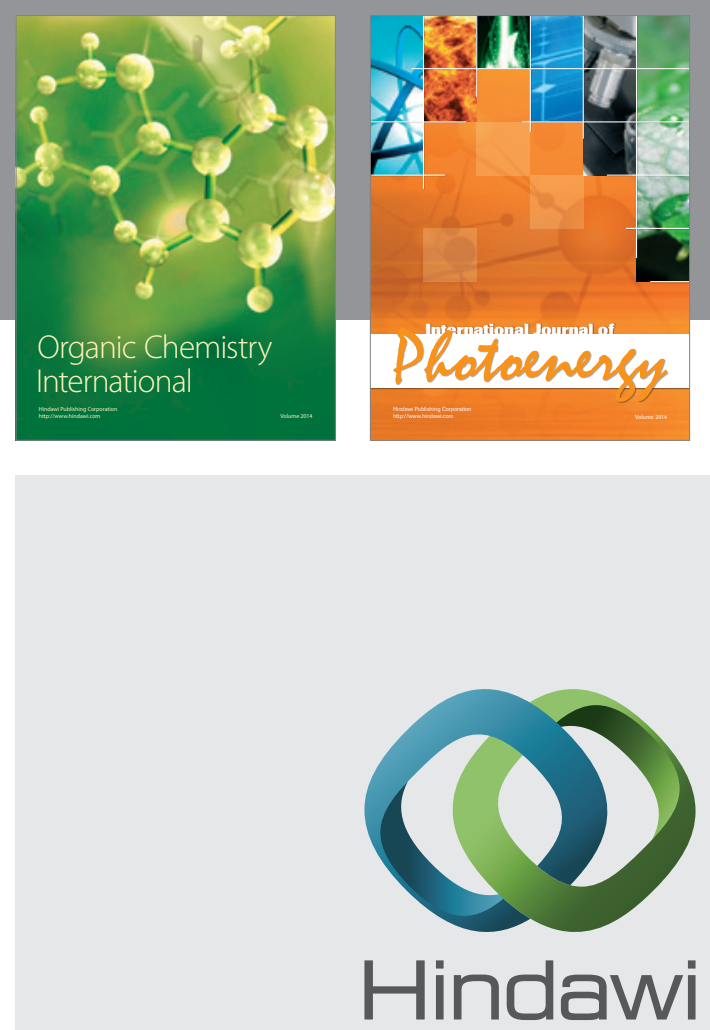

Submit your manuscripts at

http://www.hindawi.com
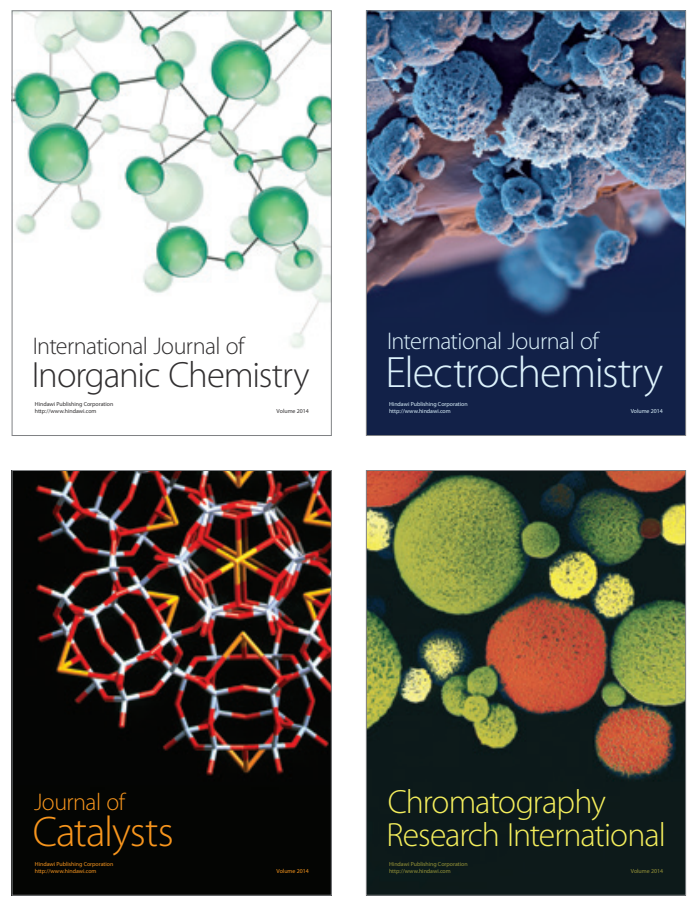
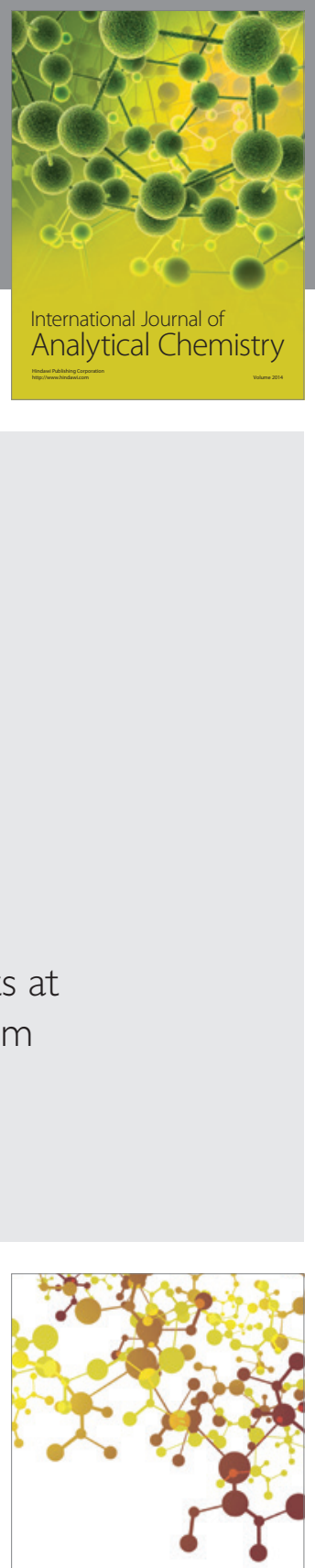

Journal of

Applied Chemistry
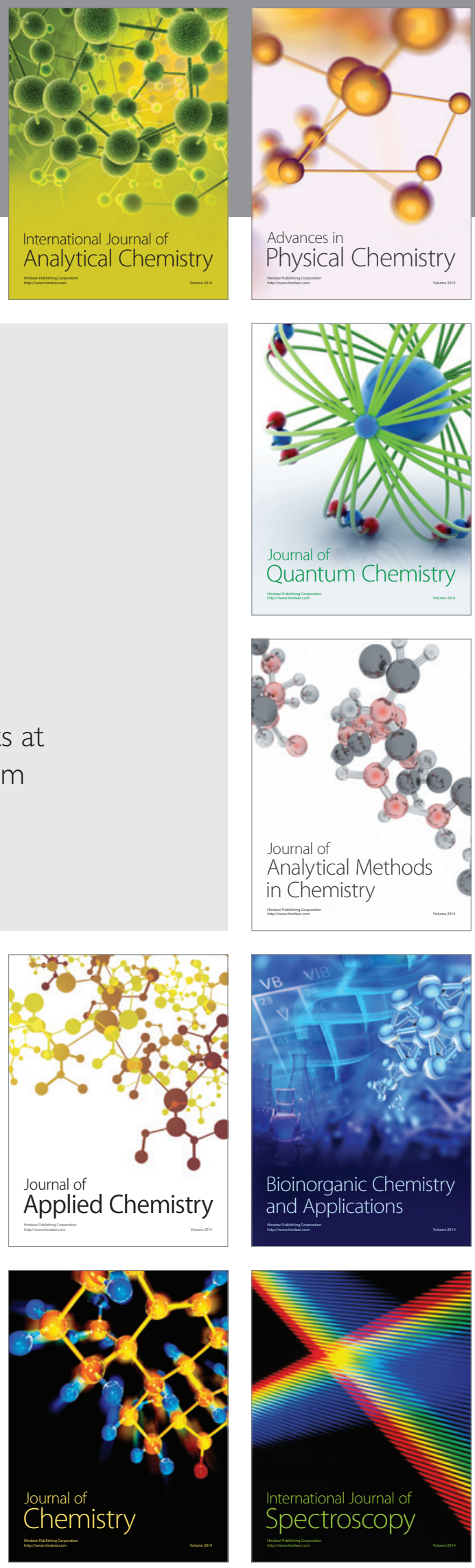